\title{
Identification and characteristics of surge-type glaciers on Novaya Zemlya, Russian Arctic
}

\author{
Katie L. GRANT, ${ }^{1}$ Chris R. STOKES, ${ }^{2}$ Ian S. EVANS ${ }^{2}$ \\ ${ }^{1}$ Department of Geography, University of Reading, Whiteknights, PO Box 227, Reading RG6 6AB, UK \\ E-mail: k.l.grant@reading.ac.uk \\ ${ }^{2}$ Department of Geography, Durham University, South Road, Durham DH1 3LE, UK
}

\begin{abstract}
We present a comprehensive new inventory of surge-type glaciers on the Novaya Zemlya archipelago, using high-resolution (up to $4 \mathrm{~m}$ ) satellite imagery from 1976/77 (Hexagon), 1989 (Landsat TM), 2001 (Landsat ETM+) and 2006 (ASTER). A total of 692 glaciers and their forelands were observed for glaciological and geomorphological criteria indicative of glacier surging (e.g. looped moraines, heavy surface crevassing, surface potholes, thrust-block moraines, concertina eskers). This enabled the identification of 32 potential surge-type glaciers (compared with four previously identified) representing $4.6 \%$ of the total but $18 \%$ by glacier area. We assess the characteristics of surge-type glaciers. Surgetype glaciers are statistically different from non-surge-type glaciers in terms of their area, length, surface slope, minimum elevation, mid-range elevation and terminus type. They are typically long (median length $18.5 \mathrm{~km}$ ), large (median area $106.8 \mathrm{~km}^{2}$ ) outlet glaciers, with relatively low overall surface slopes (median slope $1.7^{\circ}$ ) and tend to terminate in water (marine or lacustrine). They are predominantly directed towards and located in the more maritime western region of the Russian Arctic, and we suggest that surge occurrence might be related to large and complex catchment areas that receive increased delivery of precipitation from the Barents Sea.
\end{abstract}

\section{INTRODUCTION}

The sensitivity of glaciers to the climate system means that they provide a visible and measurable indicator of climate change and variability (Lemke and others, 2007). Mountain glaciers are receding across the globe and it is widely accepted that they are responding to 20th-century climate warming which is very likely due to increased greenhouse gas emissions (Pachauri and Reisinger, 2007). This warming trend is thought to be amplified in Arctic regions (Serreze and Francis, 2006), where it is becoming increasingly important to monitor glacier behaviour and their potential impact on sea level (e.g. in Greenland (Howat and others, 2007), Alaska (Arendt and others, 2002), Arctic Canada (Dyurgerov and McCabe, 2006), Svalbard (Hagen and others, 2003) and the Russian High Arctic (Glazovskiy, 1996; Glazovskiy and Macheret, 2006)).

The goal of many of these studies is to measure changes in glacier behaviour and determine their coupling to the ocean-climate system, thereby enabling improved predictions of their future response. However, glacier response can be complex and is often modulated by a number of factors that are controlled by internal glaciological factors (such as subglacial drainage systems and internal stresses). Surgetype glaciers are particularly widespread in the Arctic, and their periodic cycle of advance and retreat is not always directly coupled to climate forcing (Meier and Post, 1969; Clarke, 1987), although in some cases, surge initiation has been shown to be related to specific climate and glacier mass-balance conditions (Eisen and others, 2001). Identification of surge-type glaciers is of utmost importance when attempting to decipher the response of Arctic glaciers to climate change, and the distribution of surge-type glaciers is an important constraint when attempting to determine the controls on their behaviour (e.g. Jiskoot and others, 1998, 2003). Identification of specific environmental/glaciological controls aids development of a better understanding of the mechanisms that facilitate fast glacier flow and, where applicable, assessment of the likelihood of future surgerelated hazards such as outburst floods (Bruce and others, 1987; Kamb, 1987).

We present a new and comprehensive inventory of surgetype glaciers on the archipelago of Novaya Zemlya, Russian High Arctic. These islands are situated off the north coast of Russia at latitudes $70-77^{\circ} \mathrm{N}$, and support approximately $24400 \mathrm{~km}^{2}$ of ice (Dowdeswell and Williams, 1997). Although no comprehensive survey of surging has previously been undertaken, a small number (four) of surge-type glaciers have been reported from this location (Dowdeswell and Williams, 1997; Sharov, 2005). Here we use a temporally and spatially more comprehensive set of satellite images than previous workers to record both glaciological (Copland and others, 2003) and geomorphological (Evans and Rea, 2003) criteria of surge-type glaciers and to systematically document their occurrence. Glacier attributes (length, area, etc.) are also recorded and we analyse these quantitatively in order to assess whether there are statistical differences between the characteristics of surge- and nonsurge-type glaciers on Novaya Zemlya.

\section{STUDY AREA}

Novaya Zemlya lies north of the Russian mainland, between the Barents and Kara Seas, and forms a geological extension of the Polar Urals (Fig. 1). The islands are characterized by rugged mountain terrain, reaching maximum elevations of 1340 and $1596 \mathrm{~m}$ a.s.I. on the main south and north islands respectively (Kotlyakov, 1978). The first glaciological investigations on Novaya Zemlya began in the early 20th century, and many of these findings were later synthesized in the Catalogue of glaciers USSR (Kotlyakov, 1978), which 
a

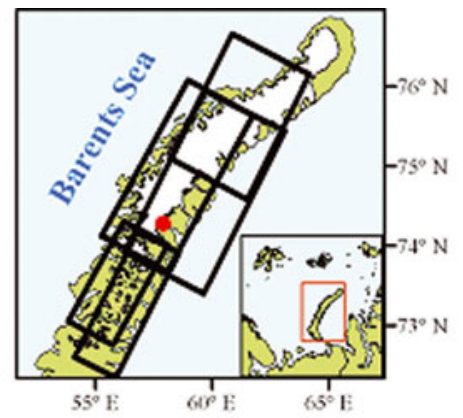

b

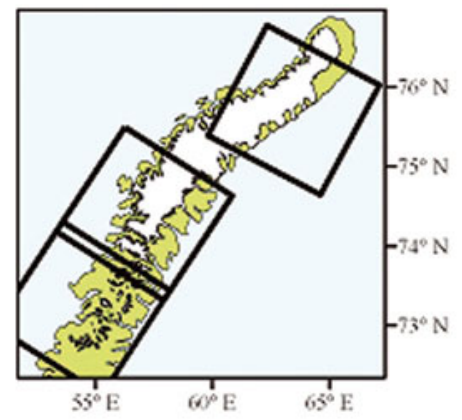

c
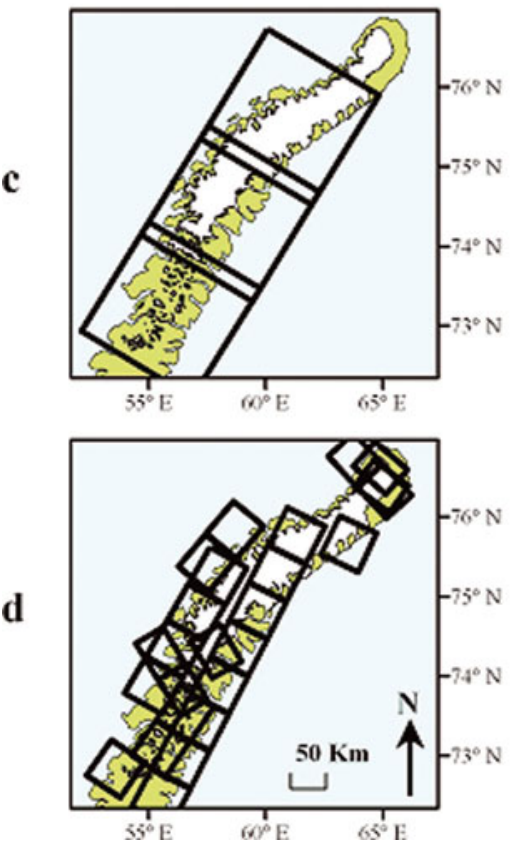
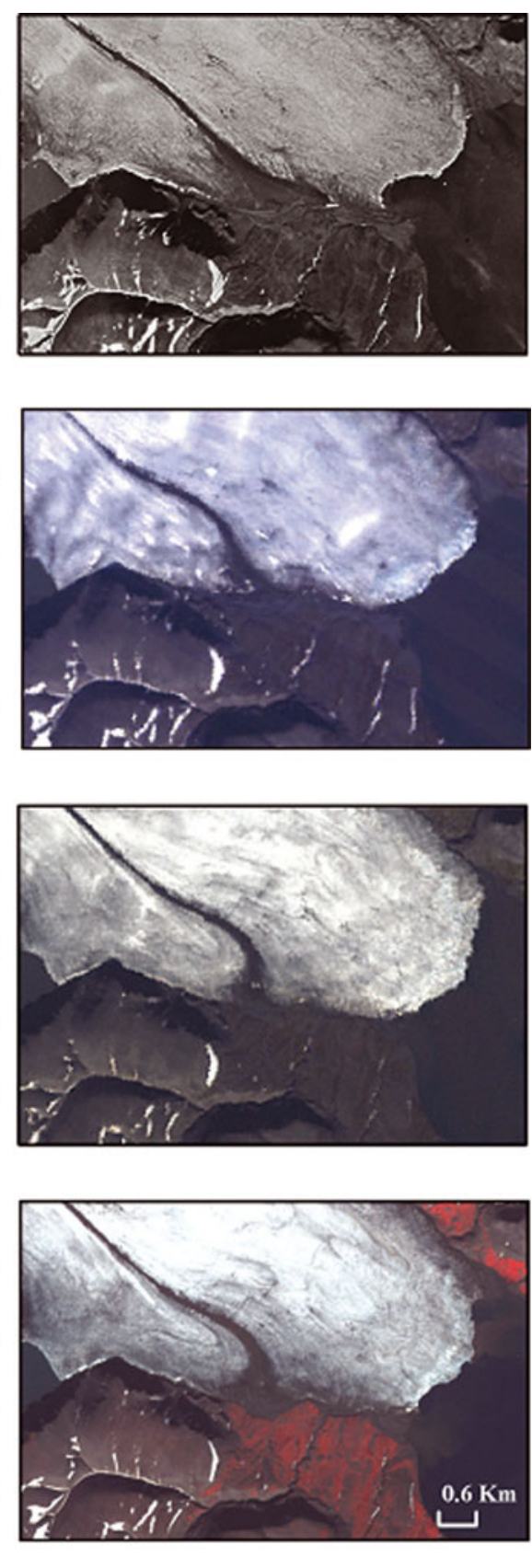

Fig. 1. (Left) Location of Novaya Zemlya (red box in inset) and coverage of: (a) 22 July 1976/6 August 1977 'Hexagon' imagery; (b) 6 August 1989 Landsat TM imagery; (c) 8 August 2001 Landsat ETM+ imagery; (d) July/August 2006 ASTER imagery. (Right) Glacier No. 60 included as an example, location indicated by red marker in (a).

represents the most complete study of glaciation on the islands and documents data on 685 glaciers.

Glaciers on Novaya Zemlya are thought to be predominantly cold-based (Zeeberg, 1997), and according to Kotlyakov (1978) there are 67 outlet glaciers radiating from the northern ice cap, 28 ice domes, 560 mountain glaciers and 32 glaciers of a type transitional between outlet and mountain glaciers. Many of the outlet glaciers from the main ice cap, on the northern island, terminate in the sea (Kotlyakov, 1978), with calving playing an important role in glacier mass balance. Further south, numerous valley glaciers form part of large icefields and transection glacier complexes. The majority of these glaciers terminate on land or in proglacial lakes, which are impounded by moraines that have formed following retreat from a recent maximum which has been linked to Little Ice Age (LIA) cooling (Zeeberg and Forman, 2001).

The substantial inventory in the Catalogue of glaciers USSR (Kotlyakov, 1978) has not been subsequently updated, and recent studies have tended to focus on the behaviour of a few large outlet glaciers, particularly those which emanate from the main ice cap on the north island (e.g. Zeeberg and Forman, 2001; Sharov, 2005). The glaciers on Novaya Zemlya are thought to have reached their maximum LIA extent towards the end of the 19th century (Zeeberg and others, 2003) and have since receded at varying rates (Zeeberg and Forman, 2001; Sharov, 2005). For a small sample $(<20)$ of tidewater glaciers on northernmost Novaya Zemlya, $75-100 \%$ of their net 20th-century retreat had occurred by 1952, followed by a slower recession and/or 
Table 1. Glaciological and geomorphological criteria for identifying surge-type glaciers (from Copland and others, 2003; Evans and Rea, 2003; Ottesen and Dowdeswell, 2006; Evans and others, 2007; Ottesen and others, 2008)

Criteria Description

Glaciological*

1. Looped moraines

2. Deformed ice structures

3. Shear margins on the glacier surface

4. Heavy surface crevassing

5. High surface velocities

6. Rapid advance of the glacier terminus

7. Highly digitate tidewater terminus

8. Strandlines of ice

9. Surface potholes

Geomorphological

1. Thrust-block/push moraines

2. Overridden thrust-block moraines

3. Concertina/zigzag eskers

4. Crevasse-squeeze ridges

5. Flutings

6. Hummocky moraine

7. Ice-cored outwash and glacilacustrine sediments
Produced when medial moraines are deformed due to the combination of fast- and slow-

flowing ice within adjacent glaciers

Form in a similar manner to looped moraines

Develop at the boundary between fast- and slow-flowing ice

Indicative of the active phase of the surge cycle and develop due to increased longitudinal stresses

Occur during the surge phase

Indicative of the active phase of the surge cycle

Terminus is splayed into lobes by longitudinal crevasses

Formed on the adjacent valley sides due to rapid thinning of the upper part of the glacier

Typically appear during the quiescent phase; they form in crevasses formed during the surge phase or in depressions between transverse ridges

Form as a result of marginal thrusting due to ice advance into proglacial sediments and can result in belts of arcuate thrust ridges. In areas where sediment is limited, low-amplitude push moraines develop

Former thrust blocks are overridden by ice and form ice-moulded 'cupola' hills

Develop during short-lived, high-discharge flood events which occur just prior to or immediately after surge termination

Commonly form in response to the highly crevassed glacier. On termination of the surge, water-saturated sediments rise into the basal crevasses and are subsequently preserved in the foreground as a series of cross-cutting diamicton ridges

Can indicate evidence for rapid advance over significant distances but are not solely diagnostic of glacier surging. They often occur in association with crevasse-squeezed ridges Produced in belts at the margin of glaciers and consist of a chaotic landscape with kame and kettle topography, which evolves from the thrusting, squeezing and bulldozing of sediments and meltout of buried glacier ice (However, other origins are possible)

Form in low-lying areas of the glacier snout and may be buried by large outwash fans and glacilacustrine sediments. Subsequent modification by meltout of underlying ice leads to a typically pitted, hummocky surface

*From Copland and others (2003).

${ }^{\dagger}$ From Evans and Rea (2003); Ottesen and Dowdeswell (2006); Ottesen and others (2008).

stabilization until 1993 (Zeeberg and Forman, 2001). Sharov (2005) reported variable retreat rates of 21 glaciers since 1952, except for one glacier that advanced and which, it has been suggested, may be a surge-type glacier.

The existence of surge-type glaciers on Novaya Zemlya was first suggested by Koryakin (1974) and Kotlyakov (1978). More recently, as part of a larger study (including Franz Josef Land and Severnaya Zemlya), Dowdeswell and Williams (1997) used Landsat Thematic Mapper (TM) imagery to search for surge-type glaciers on Novaya Zemlya. They used a single scene from 1986 covering $80 \%$ of the glacierized area of the northern island to identify looped medial moraines, potholes on the glacier surface and extensive crevassing, all of which are thought to be indicative of past surge behaviour. Their study revealed that surge features were present on three glaciers, and Sharov (2005) documented further evidence for surging on one other glacier on the north island. The Catalogue of glaciers USSR (Kotlyakov, 1978) mentioned seven surgetype glaciers, all of which are located south of all the surgetype glaciers found in this study and consist of small valley and mountain glaciers. It is unclear on what evidence this suggestion was based, particularly as these glaciers showed no signs of surge evidence when checked on imagery used in this study.

\section{CRITERIA FOR IDENTIFICATION OF SURGE-TYPE GLACIERS}

Although glacier surging is a complex process known to cover a broad spectrum of behaviours and characteristics (Meier and Post, 1969), a surge-type glacier can generally be described as one which undergoes cyclic fluctuations in velocity characterized by two phases: (1) a short (a few months to a few years) surge/active phase during which flow velocities increase by at least an order of magnitude and ice is rapidly transferred down-glacier, usually resulting in advance of the terminus and thinning of the upper zone; (2) a longer (tens to a few hundreds of years) quiescent phase which occurs between surges, during which ice builds up in the accumulation area and ice nearer the terminus stagnates and melts in situ (Copland and others, 2003). Due to the short duration of the surge phase and lack of continuous glacier monitoring, few glaciers have been observed throughout the surge cycle. Past surge activity can be recognized, however, from a combination of diagnostic glaciological (Copland and others, 2003; Dowdeswell and others, 2007) and geomorphological criteria (Evans and Rea, 2003; Ottesen and Dowdeswell, 2006; Evans and others, 2007; Kjær and others, 2008; Ottesen and others, 2008). These criteria, listed in Table 1, enable identification of surge-type glaciers irrespective of whether they are actively 
Table 2. Imagery used to identify surge-type glaciers on Novaya Zemlya

\begin{tabular}{|c|c|c|c|c|c|}
\hline \multirow[t]{2}{*}{ Sensor } & \multirow{2}{*}{$\begin{array}{l}\text { Spatial resolution } \\
\text { m }\end{array}$} & \multirow{2}{*}{$\begin{array}{l}\text { Spectral bands } \\
\qquad \mu \mathrm{m}\end{array}$} & \multirow[t]{2}{*}{ Date } & \multirow{2}{*}{$\begin{array}{c}\text { Coverage of glaciers } \\
(\% \text { of glaciated area }) \\
\mathrm{km}^{2}\end{array}$} & \multirow[t]{2}{*}{ Source } \\
\hline & & & & & \\
\hline KH-9 'Hexagon' (Fig. 1a) & 4 & $\mathrm{~N} / \mathrm{A}$ & $\begin{array}{l}22 \text { Jul } 1976 \\
6 \text { Aug } 1977\end{array}$ & $21000(91 \%)$ & $\begin{array}{c}\text { USGS } \\
\text { (http://earthexplorer.usgs.gov) }\end{array}$ \\
\hline Landsat TM (Fig. 1b) & $\begin{array}{c}\text { Bands } 1-5,7: 27.5 / \\
30 ; \text { band } 6: 60\end{array}$ & $\begin{array}{c}\text { 1: } 0.45-0.52 \\
\text { 2: } 0.52-0.60 \\
\text { 3: } 0.63-0.69 \\
\text { 4: } 0.76-0.90 \\
5: 1.55-1.75 \\
6: 10.40-12.50 \\
\text { 7: } 2.08-2.35\end{array}$ & 6 Aug 1989 & $18000(78 \%)$ & $\begin{array}{c}\text { GLCF } \\
\text { (www.landcover.org) }\end{array}$ \\
\hline Landsat ETM+ (Fig. 1c) & $\begin{array}{c}\text { Bands } 1-5,7: 30 \\
\text { band } 6: 60 ; \\
\text { band } 8: 15\end{array}$ & $\begin{array}{l}\text { 1: } 0.45-0.52 \\
\text { 2: } 0.53-0.61 \\
\text { 3: } 0.63-0.69 \\
\text { 4: } 0.78-0.90 \\
\text { 5: } 1.55-1.75 \\
\text { 6: } 10.4-12.5 \\
\text { 7: } 2.09-2.35 \\
\text { 8: } 0.52-0.90\end{array}$ & 8 Aug 2001 & $21000(91 \%)$ & $\begin{array}{c}\text { GLCF } \\
\text { (www.landcover.org) }\end{array}$ \\
\hline ASTER (Fig. 1d) & 15 & $\begin{array}{c}\text { B1: } 0.52-0.60 \\
\text { B2: } 0.63-0.69 \\
\text { B3: } 0.76-0.86 \text { (nadir) } \\
\text { B4: 0.76-0.86 (backward) } \\
\text { B5: } 1.60-1.70 \\
\text { B6: } 2.16-2.19 \\
\text { B7: } 2.19-2.23 \\
\text { B8: } 2.24-2.29 \\
\text { B9: } 2.30-2.37 \\
\text { B10: } 2.36-2.43 \\
\text { B11: } 8.13-8.48 \\
\text { B12: } 8.48-8.83 \\
\text { B13: } 8.93-9.28 \\
\text { B14: } 10.25-10.95 \\
\text { B15: } 10.95-11.65\end{array}$ & $\begin{array}{l}\text { Various dates in Jul/ } \\
\text { Aug } 2006\end{array}$ & $18000(78 \%)$ & $\begin{array}{c}\text { NASA EOS } \\
\text { (http://delenn.gsfc.nasa.gov/ } \\
\text { ims-bin/pub/nph-ims.cgi) }\end{array}$ \\
\hline
\end{tabular}

Note: GLCF: Global Land Cover Facility; EOS: Earth Observing System.

surging or not. Moreover, their identification is well suited to observation by satellite imagery, which permits large numbers of glaciers to be inspected very efficiently.

\section{METHODS}

As part of a larger study investigating recent glacier change in Novaya Zemlya (to be reported elsewhere), numerous satellite images have been acquired that provide complete coverage of glaciers on the archipelago at various dates over the last four decades. In this study, we use KH-9 'Hexagon', Landsat TM, Landsat Enhanced TM+ (ETM+) and Advanced Spaceborne Thermal Emission and Reflection Radiometer (ASTER) imagery to identify the features diagnostic of surging activity (Table 1). The spatial and spectral resolution of the imagery is detailed in Table 2, and the imagery coverage is shown in Figure 1. Images were acquired in July or August, when snow cover was at a minimum late in the ablation season, thereby enabling more accurate identification of surge-type features. The enhanced spatial and temporal coverage of this study is an advance on that used in previous work (e.g. Dowdeswell and Williams, 1997), and the resolution of the imagery (up to $4 \mathrm{~m}$ ) allows subtle geomorphological features to be identified in the glacier forelands (e.g. concertina eskers, thrust-block moraines, etc.). Additionally, the imagery in this study extends from 1976 to 2006, with many of the glaciers visible at several dates, thus increasing the timescale over which the criteria for surge behaviour may be identified (Fig. 1).

The 685 glaciers in the Catalogue of glaciers USSR (Kotlyakov, 1978) were incorporated into the World Glacier Inventory (WGI). Using the latitude/longitude coordinates and other attributes (e.g. aspect, length, area) from the WGI, it was possible to confidently identify 522 glaciers from the WGI on the satellite imagery. These glaciers are thus referred to by their WGI identification number. Unfortunately, the remaining 163 glaciers from the WGI could not be located on the satellite imagery, largely due to an apparent mismatch in glacier coordinates. These glaciers, and an additional seven glaciers that were not included in the WGI are referred to using an ID based upon latitude and longitude, following the Global Land Ice Measurements from Space (GLIMS) protocol (Raup and others, 2007). Thus, our complete dataset consists of 692 glaciers. Although the smallest glacier in this dataset is measured at $0.1 \mathrm{~km}^{2}$, it is likely that other small glaciers are missing from the WGI and our dataset. As the probability of surge behaviour is highly correlated with glacier length (Clarke, 1991; Jiskoot and others, 1998), it is unlikely that any surge-type glaciers are among the small glaciers that may have been omitted. 

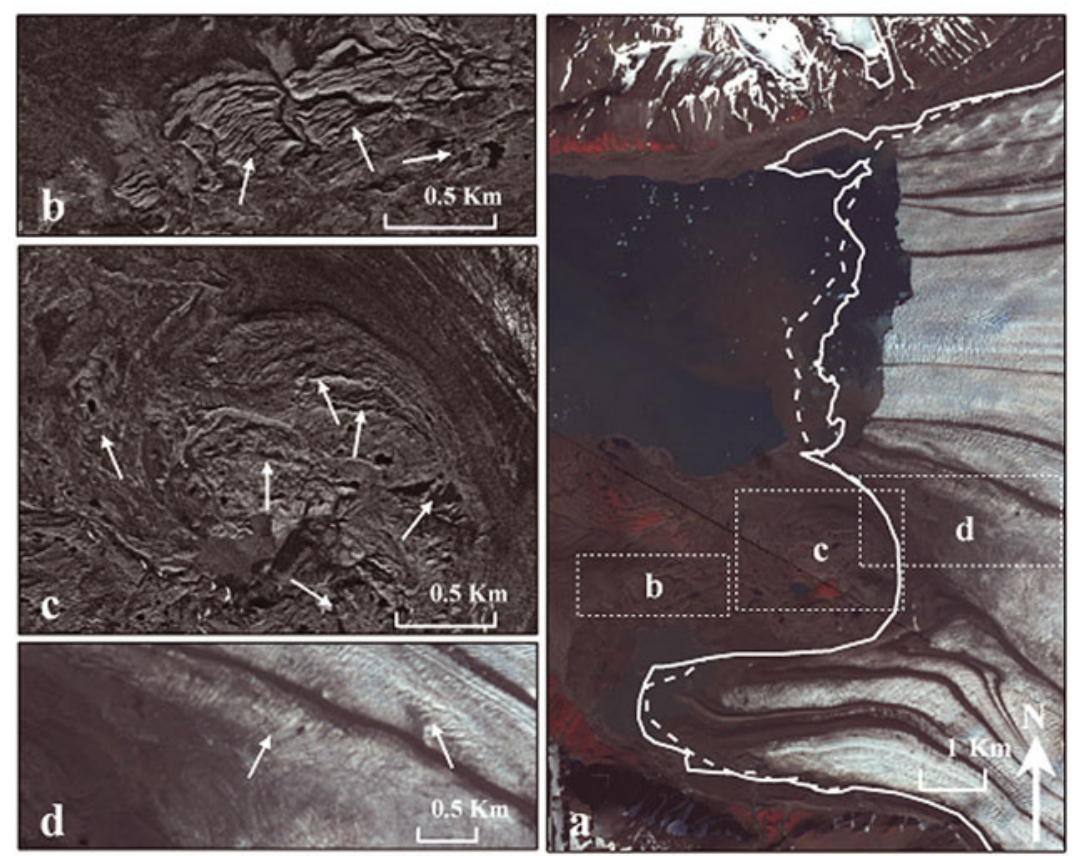

Fig. 2. Glaciological and geomorphological features identified on glacier No. 66, a type 1 surging glacier. (a) 2006 ASTER imagery. The solid white line represents the extent in 1976, and the dashed white line the extent in 1989, an advance of 600 m. Note the presence of looped moraines, extensive crevassing and the digitate nature of the terminus. The white arrows identify the following features: (b) thrust-block and hummocky moraines in 1976 'Hexagon' imagery; (c) hummocky moraine, concertina eskers and crevasse-squeeze ridges in 1976 'Hexagon' imagery; (d) deformed ice structures and shear margins in 2006 ASTER imagery.

Each of the 692 glaciers in our dataset was systematically examined on the imagery on which it was visible, and the presence or absence of features diagnostic of glacier surging (Table 1) was recorded. The glaciers were then categorized according to the following index based on Copland and others (2003):

1. confirmed surging: active surge phase observed and three or more distinct surge features

2. likely to have surged: three or more distinct surge features, but active phase not observed

3. possibly surged: less than three surge features present, active phase not observed

4. non-surge: no surge features present.

It is important to note that some of the surge-type features outlined in Table 1 can occur on both surge-type and nonsurge-type glaciers, so it is the combination of these features which indicates surging behaviour. Whilst it is relatively unusual to observe the active surge phase using satellite imagery alone, if a glacier has shown significant advance (several hundreds of metres) between two images separated little temporally ( $<\sim 15$ years) and displays three or more distinct surge features on the more recent imagery, then it is categorized as type 1.

In addition to the presence/absence of surge criteria, other glacier attributes were recorded in the database (e.g. length, area, elevation, aspect, terminus environment, etc.). Glaciers were also classified according to the World Glacier Monitoring Service's protocol (UNESCO/IAHS, 1970), as outlet glaciers, valley glaciers or mountain glaciers. The 522 glaciers that were successfully matched to the WGI were cross-checked and updated for agreement with observations on our satellite imagery. For the 170 glaciers that were not matched to the WGI, the glacier attribute data were measured using the satellite imagery. Measuring glacier length and area was occasionally complicated by the difficulty in accurately identifying ice divides, but estimates were possible based on surface flow features and topographic maps at a scale of $1: 200000$ generated from 1952 aerial photography (contour interval $40 \mathrm{~m}$ ). Potential errors in these estimations are deemed insignificant when grouping glaciers into relatively large size classes for our analysis (e.g. length classes of 1-6 km, 6.1-11 km, etc.). Accurate elevation data were impossible to measure using satellite imagery but were available for 516 of the 522 glaciers from the WGI. Although glacier elevations may have changed since their measurements recorded in the WGI (particularly terminus elevations), such changes are likely to be consistent and not important when comparing surge vs non-surge glacier types.

\section{RESULTS}

\section{Identification and distribution of surge-type glaciers}

A total of 692 glaciers were inspected for indications of surge behaviour. The vast majority of these glaciers were of non-surge type, but 32 glaciers (4.6\%) showed evidence of possible surge activity. Table 3 shows all the glaciers identified as showing signs of surging, with the presence/ absence of different criteria. Of the 32 possible surge-type glaciers, 4 were categorized as type 1 (confirmed), 13 as type 2 (likely) and 15 as type 3 (possible). Figure 2 shows an example of a type 1 surging glacier which displays many of the glaciological and geomorphological criteria identified in Table 1. 
Table 3. Surge-type glaciers in Novaya Zemlya. Lettering refers to the year the feature was present: a. 1976/77; b. 1989; c. 2001; d. 2006. The index refers to the classification of the glacier: 1 . confirmed surging: active surge phase observed, three or more distinct surface features; 2. likely to have surged: three or more distinct surge features, but active phase not observed; 3 . possibly surged: less than three surge features present, active phase not observed. Glacier ID numbers are from WGI except for two where latitude and longitude had to be used

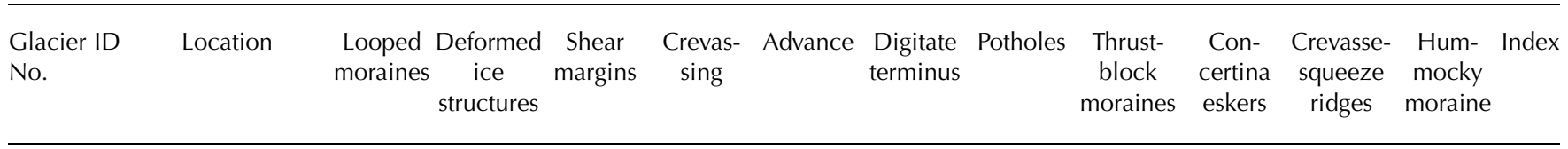

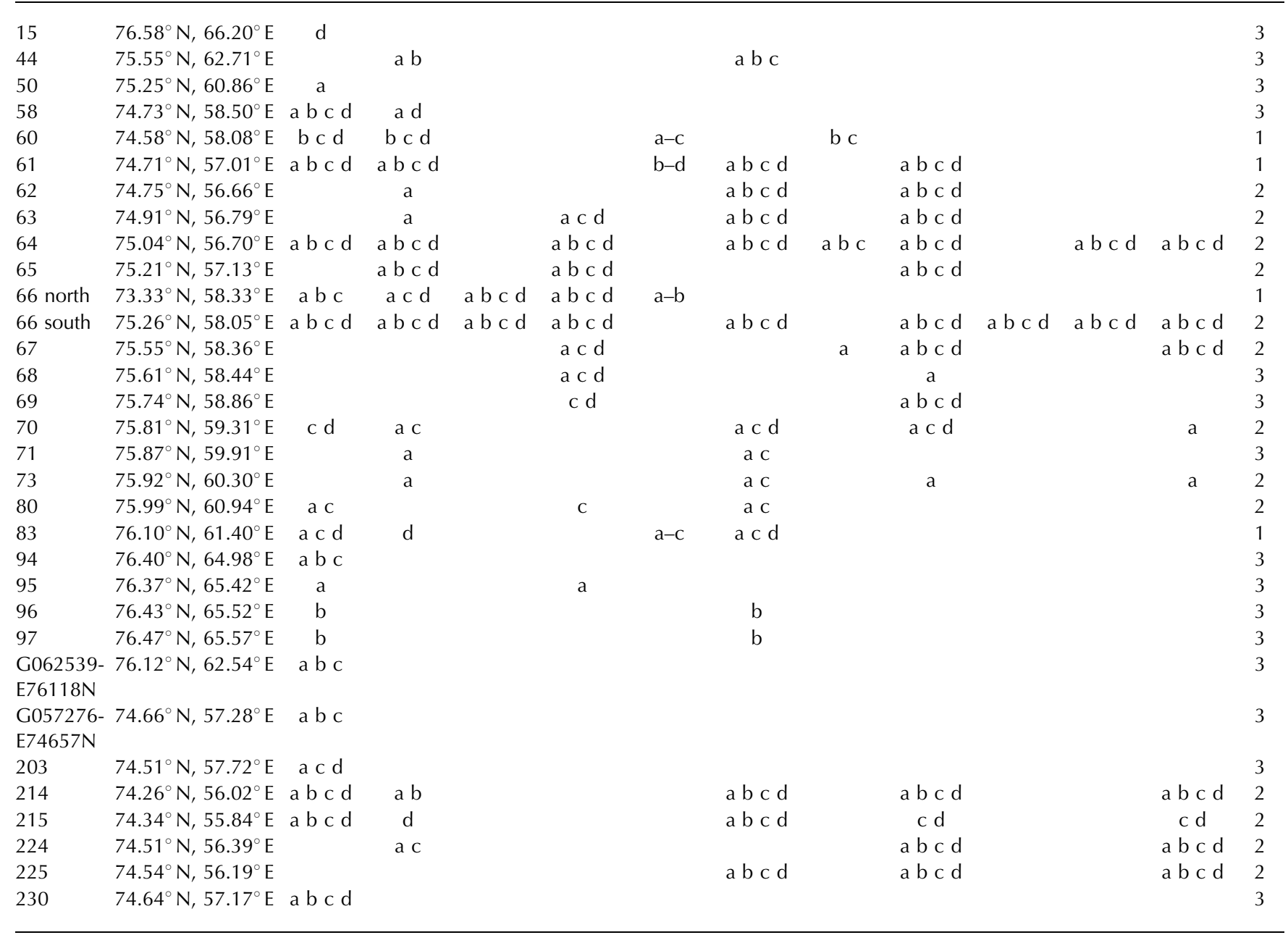

The 32 potential surge-type glaciers might represent a minimum estimate of the number of surge-type glaciers since surge features are not always easy to identify and may have been reworked and removed by subsequent glaciological and geomorphological processes (Copland and others, 2003). Conversely, it could be argued that the 15 type 3 glaciers ('possibly surged') do not show convincing evidence of surge activity. However, we note that all but three of this class show evidence of looped moraines, which are thought to be one of the most robust indications of surge activity in the absence of direct observation (Dowdeswell and Williams, 1997; Copland and others, 2003).

The location of the 32 potential surge-type glaciers is shown in Figure 3, which indicates that they predominantly occur on the western margin of the largest ice cap on the north island, although several also emanate from two smaller icefields to the south. No surge-type glaciers were observed among the valley and mountain glacier systems which dominate south of $\sim 74^{\circ} \mathrm{N}$, where the maximum glacier length is around $12 \mathrm{~km}$.

\section{Characteristics of surge-type glaciers}

In order to investigate the characteristics of surge-type versus non-surge-type glaciers, a number of glacier attributes were compared and statistically analysed. Initially, 57 ice masses classified as glacierets or snowfields were excluded from the dataset. This is because it is extremely difficult to determine from satellite imagery whether such ice bodies still experience ice movement. Thus, a total of 635 glaciers were included in the analysis, of which 32 were identified as possibly surge-type. For analysis involving elevation data, totals of only 462 (mid-range elevation), 463 (maximum elevation) and 464 (minimum elevation) glaciers could be used, due to missing data. These included 30 surge-type glaciers. The positively skewed distributions of length, area and overall surface slope data were log-transformed prior to analysis.

All 32 glaciers with surge evidence are outlet glaciers emanating from large ice caps. They are longer, larger and of lower slope than most glaciers (Fig. 4; Table 4). All are north of $74.25^{\circ} \mathrm{N}$, have lengths $\geq 7 \mathrm{~km}$, areas $\geq 19 \mathrm{~km}^{2}$, height ranges $\geq 350 \mathrm{~m}$ and gradients $<5.4^{\circ}$. These 32 glaciers 


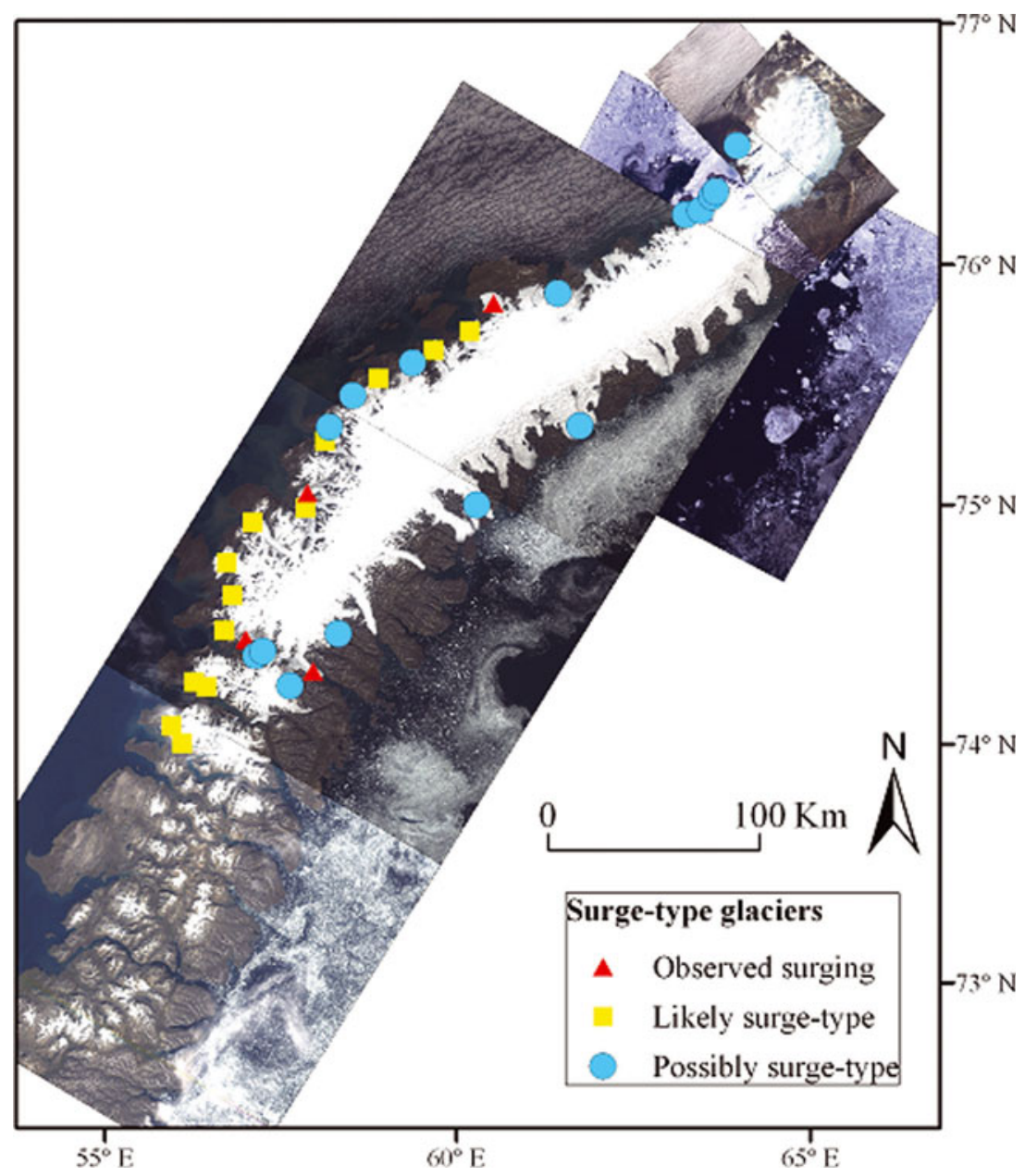

Fig. 3. Location of surge-type glaciers on Novaya Zemlya. Background images: 1989 and 2001 Landsat imagery and 2006 ASTER imagery.

constitute $5 \%$ of all glaciers; $12.1 \%$ of the 264 outlet glaciers and $12.1 \%$ of the 265 glaciers north of $74.25^{\circ} \mathrm{N}$; $25.8 \%$ of the 124 glaciers $7 \mathrm{~km}$ or longer; and $37 \%$ of the 86 glaciers $19 \mathrm{~km}^{2}$ or more in area. Allowing for missing data, glaciers with surge evidence constitute $9.8 \%$ of those $350 \mathrm{~m}$ or more in height range, and $22.2 \%$ of those of slope $<5.4^{\circ}$. The 30 with a full dataset constitute $41 \%$ of the glaciers with all three size criteria, and $52.6 \%$ of those with all six criteria.

Taking the above subdivision of surge-type glaciers into account, the size effect is even stronger. The shortest type 1 glacier (confirmed surge) is $23 \mathrm{~km}$, and the shortest type 2 (likely) is $13 \mathrm{~km}$. The smallest type 1 is $138 \mathrm{~km}^{2}$, and the smallest type 2 is $59 \mathrm{~km}^{2}$.

Glacier length and glacier area are strongly correlated $\left(R^{2}=92 \%\right.$ for log length with log area), so it follows that surge-type glaciers also have larger surface areas than nonsurge-type glaciers. The total area of surge-type glaciers is $\sim 4245 \mathrm{~km}^{2}$, representing $\sim 18 \%$ of the total glacier area (estimated at $\sim 22984 \mathrm{~km}^{2}$ here, compared with $24400 \mathrm{~km}^{2}$ by Dowdeswell and Williams, 1997). Overall surface slope shows that surge-type glaciers generally have lower surface slopes than non-surge-type glaciers (Fig. 4; Table 4). In terms of the minimum, maximum and mid-range elevation, nonsurge-type glaciers as a group show a greater range than surge-type glaciers, with surge-type glaciers typically reaching lower elevations (Fig. 5; Table 4).

One-way analysis of variance (ANOVA) tests were used to establish whether there were statistically significant differences between the length, area and elevation characteristics of surge vs non-surge glaciers. All potential surge-type glaciers (32) were grouped together (i.e. assumed to be surge-type), and results reveal that there are statistically significant differences between the length, area, overall surface slope, minimum elevation and mid-range elevation, but not maximum elevation (Table 4). Glacier area reveals the strongest relationship $(F=188.03 ; p \leq 0.0000)$, followed by length, overall surface slope, minimum elevation and mid-range elevation. However, because overall surface slope is calculated from the height range and length data, the relation between surface slope and surging is probably an indirect effect of the correlation between glacier length and surging.

Although all glaciers classified as surge-type are outlet glaciers, only $38 \%$ of non-surge-type glaciers are outlet glaciers; the remainder are classified as either valley or mountain glaciers. In order to ascertain any differences between the surge-type and non-surge-type outlet glaciers, therefore, the same statistical tests were performed on the outlet glaciers alone $(n=264)$. These analyses reveal the same statistically significant differences, as do further tests confined to outlet glaciers $>6.5 \mathrm{~km}$ long $(n=117)$ (Table 4).

Glacier aspect data reveal that $63 \%$ of identified surgetype glaciers face in a westerly direction (northwest, west, southwest), compared with only $24 \%$ of non-surge-type glaciers. In contrast, $44 \%$ of non-surge-type glaciers face in an easterly direction (northeast, east, southeast), compared to only $19 \%$ of surge-type glaciers. Clearly, surge-type glaciers favour westward aspects, with a vector mean of 
Table 4. Comparative data between surge-type and non-surge-type glaciers and results of one-way ANOVA tests. Statistically significant relationships are highlighted in grey; ${ }^{*}$ indicates data were log-transformed $\left(\log _{10}(x)\right)$

\begin{tabular}{|c|c|c|c|c|c|c|c|}
\hline & \multirow[t]{4}{*}{ Variable } & \multicolumn{6}{|c|}{ Attribute } \\
\hline & & \multirow{3}{*}{$\begin{array}{l}\text { Length } \\
\text { km }\end{array}$} & \multirow{3}{*}{$\begin{array}{l}\text { Area } \\
\mathrm{km}^{2}\end{array}$} & \multirow{3}{*}{ Overall surface slope } & \multicolumn{3}{|c|}{ Elevation } \\
\hline & & & & & Min & Max & Mid-range \\
\hline & & & & & ma.s.l. & ma.s.I & ma.s.l \\
\hline \multirow{5}{*}{ Surge-type } & $N$ & 32 & 32 & 30 & 30 & 30 & 30 \\
\hline & Mean & $\begin{array}{c}* \log =1.2772 \\
* \text { antilog }=18.93\end{array}$ & $\begin{array}{c}* \log =1.9974 \\
* \text { antilog }=99.40\end{array}$ & $\begin{array}{l}* \log =0.2719 \\
* \text { antilog }=1.87\end{array}$ & 31.23 & 698.33 & 364.77 \\
\hline & Median & 18.5 & 106.8 & 1.7 & 0 & 610 & 317 \\
\hline & Min & 7 & 19.0 & 1.0 & 0 & 380 & 190 \\
\hline & Max & 44 & 364.1 & 5.3 & 400 & 1100 & 750 \\
\hline \multirow{5}{*}{ Non-surge-type } & $N$ & 603 & 603 & 432 & 434 & 433 & 432 \\
\hline & Mean & $\begin{array}{c}{ }^{*} \log =0.4472 \\
* \text { antilog }=2.80\end{array}$ & $\begin{array}{c}* \log =0.3569 \\
* \text { antilog }=2.27\end{array}$ & $\begin{array}{l}{ }^{*} \log =0.8904 \\
* \text { antilog }=7.77\end{array}$ & 290.28 & 737.04 & 513.91 \\
\hline & Median & 2.9 & 1.9 & 8.5 & 280 & 730 & 510 \\
\hline & Min & 0.4 & 0.1 & 0.6 & 0 & 270 & 135 \\
\hline & Max & 36 & 362.4 & 35.8 & 1000 & 1200 & 1050 \\
\hline \multirow{5}{*}{$\begin{array}{l}\text { One-way ANOVA between } \\
\text { surge-type and non-surge-type } \\
\text { glaciers }\end{array}$} & $\begin{array}{c}\text { Significant difference: } \\
\text { Y/N? }\end{array}$ & $* Y$ & $* Y$ & $* Y$ & Y & $\mathrm{N}$ & Y \\
\hline & $N$ & 635 & 635 & 462 & 464 & 463 & 462 \\
\hline & $P$ value & 0.0000 & 0.0000 & 0.0000 & 0.0000 & 0.2238 & 0.0000 \\
\hline & $F$ value & 163.67 & 188.03 & 127.77 & 64.63 & 1.48 & 34.13 \\
\hline & Adjusted $R^{2}$ value & 0.2042 & 0.2278 & 0.2157 & 0.1208 & 0.0010 & 0.0670 \\
\hline \multirow{4}{*}{$\begin{array}{l}\text { One-way ANOVA between } \\
\text { surge-type and non-surge-type } \\
\text { outlet glaciers }\end{array}$} & $\begin{array}{c}\text { Significant difference: } \\
\text { Y/N? }\end{array}$ & *Y & $* Y$ & $* Y$ & $\mathrm{Y}$ & $\mathrm{N}$ & $\mathrm{Y}$ \\
\hline & $N$ & 264 & 264 & 181 & 183 & 182 & 181 \\
\hline & $P$ value & 0.0000 & 0.0000 & 0.0000 & 0.0000 & 0.3121 & 0.0001 \\
\hline & $F$ value & 83.68 & 93.08 & 53.27 & 31.75 & 1.03 & 15.60 \\
\hline \multirow{6}{*}{$\begin{array}{l}\text { One-way ANOVA between } \\
\text { surge-type and non-surge-type } \\
\text { outlet glaciers }>6.5 \mathrm{~km} \text { long }\end{array}$} & Adjusted $R^{2}$ value & 0.2392 & 0.2593 & 0.2251 & 0.1445 & 0.0002 & 0.0750 \\
\hline & $\begin{array}{c}\text { Significant difference: } \\
\text { Y/N? }\end{array}$ & ${ }^{*} \mathrm{Y}$ & ${ }^{*} \mathrm{Y}$ & ${ }^{*} \mathrm{Y}$ & Y & $\mathrm{N}$ & Y \\
\hline & $N$ & 117 & 117 & 97 & 99 & 97 & 97 \\
\hline & $P$ value & 0.0000 & 0.0000 & 0.0001 & 0.0022 & 0.1967 & 0.0361 \\
\hline & $F$ value & 28.34 & 31.65 & 17.34 & 9.86 & 1.69 & 4.52 \\
\hline & Adjusted $R^{2}$ value & 0.1907 & 0.2090 & 0.1454 & 0.0829 & 0.0071 & 0.0354 \\
\hline
\end{tabular}

$286 \pm 39^{\circ}$, whereas other outlet glaciers in the same latitudes have a very weak northward tendency (Fig. 6).

Glacier terminus types were analysed, with glaciers classified as either terrestrial (terminating on land), marine (terminating in the ocean) or lacustrine (terminating in a proglacial lake). Termini consisting of a mixture of more than one type were categorized according to that which contacted the greatest breadth of the terminus. The vast majority of non-surge-type glaciers $(90 \%)$ have terrestrial termini, whereas for surge-type glaciers, marine $(41 \%)$ and lacustrine $(28 \%)$ termini are more common. A chi-squared $\left(\chi^{2}\right)$ test indicates that there is a statistically significant difference between the terminus types of surge-type and non-surge-type glaciers at the $99.5 \%$ confidence level.

In summary, surge-type glaciers on Novaya Zemlya are predominantly located in and directed towards the west and tend to be larger, longer and exhibit lower surface slopes compared to non-surge-type glaciers. They tend to descend to lower elevations and are thus more likely to terminate in a marine (or lacustrine) environment than non-surge-type glaciers. Their main distinguishing characteristic is large area, $>19 \mathrm{~km}^{2}$. As only one non-outlet glacier reaches this size, all surge-type glaciers are outlet glaciers. $54 \%$ of the 54 non-surge glaciers with areas over $19 \mathrm{~km}^{2}$ are land- terminating, compared with only $31 \%$ of the 32 surge-type glaciers.

\section{DISCUSSION}

\section{Occurrence of surge-type glaciers on Novaya Zemlya}

Previous work on Novaya Zemlya suggested that only a handful of surge-type glaciers exist (Kotlyakov, 1978; Dowdeswell and Williams, 1997; Sharov, 2005). In a similar study to the one undertaken here, Dowdeswell and Williams (1997) found evidence for only three surge-type glaciers. They contrasted this number to the more frequent surge occurrence in Svalbard, and suggested that the decrease in Novaya Zemlya might be related to the eastward decrease in temperature and precipitation and the increased likelihood of glaciers having a cold thermal structure. Various estimates have been given for the percentage of surge-type glaciers in Svalbard: $36 \%$ in a sample by Hamilton and Dowdeswell (1996); $26 \%$ of the 504 studied by Jiskoot and others (1998); and $13 \%$ of the 1029 larger than $1 \mathrm{~km}^{2}$ in area (Jiskoot and others, 1998). However, all these studies omitted glaciers smaller than $1 \mathrm{~km}^{2}$, and had incomplete information for 

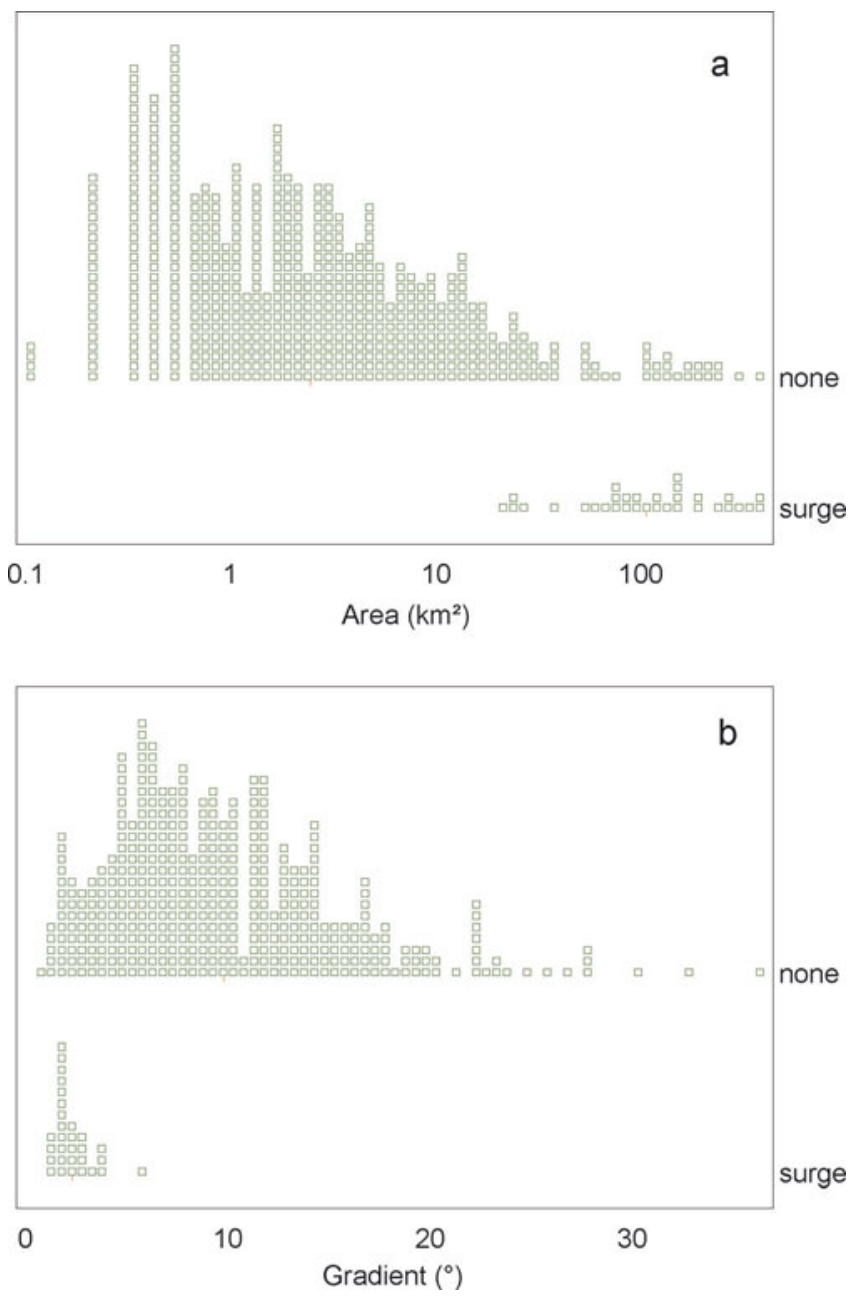

Fig. 4. Contrasts in (a) area (log scale) and (b) gradient, between 32 glaciers with any surge evidence and 603 glaciers with none. Each square is a single glacier, and the triangles are mean values. From a program by N.J. Cox (unpublished information, 2003, revised 2009).

those smaller than $5 \mathrm{~km}^{2}$; they are thus not directly comparable with our study.

Our new observations suggest that there are 32 possible surge-type glaciers on Novaya Zemlya (Table 3). This increased detection is likely to reflect the increased spatial and temporal resolution of our observations from 1976, 1989, 2001 and 2006: in their earlier reconnaissance study Dowdeswell and Williams (1997) used only a single Landsat TM scene from 1986, covering only part of the ice on Novaya Zemlya. Thus, a significant result of our study is that surge-type glaciers on Novaya Zemlya are more common than previously recognized.

Taking into consideration the size of glacier drainage basins, around $18 \%$ of the glacier area in Novaya Zemlya is surge-affected. Whilst this estimate is comparable with results from Svalbard (46-48\% of glacier area; Jiskoot and others, 1998), it is still significantly lower, probably reflecting the eastward decrease in precipitation and temperature, as suggested by Dowdeswell and Williams (1997). This contrast in precipitation and surging is even more marked between the northwest slope and the southeast slope of Novaya Zemlya's north island. Thus, our new results might imply that warm-based/polythermal conditions on Novaya Zemlya are more widespread than previously

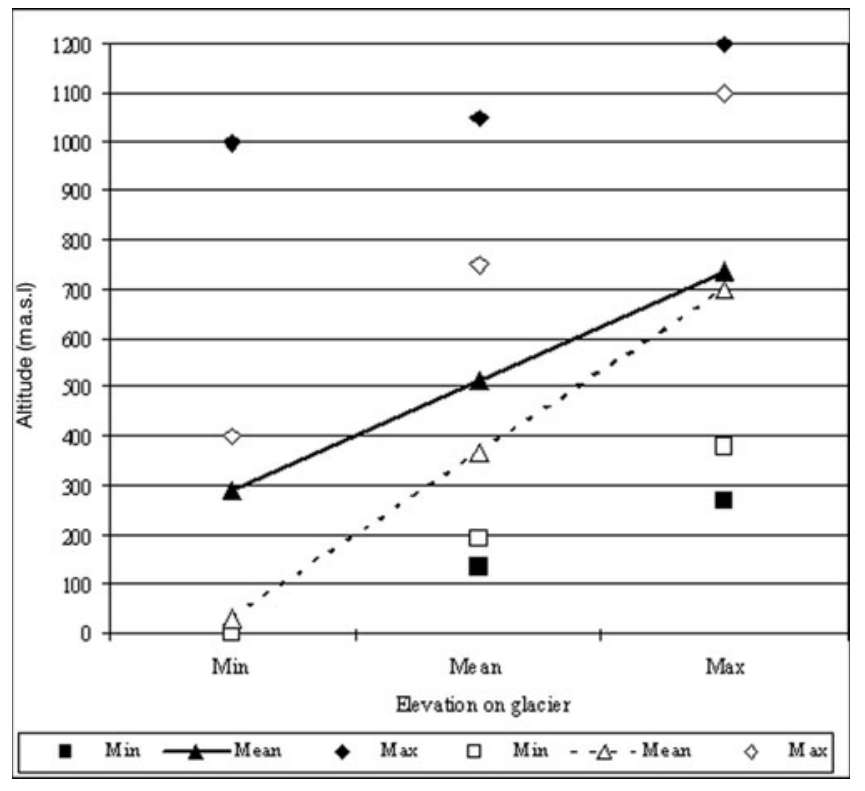

Fig. 5. Range of glacier altitude for 30 surge-type glaciers (white) and 432 non-surge-type glaciers (black) on Novaya Zemlya. 'Min' indicates elevation of glacier terminus; 'Mean' indicates glacier mid-range elevation; 'Max' indicates elevation of highest point of glacier.

recognized and/or that such conditions have become more prevalent in recent years.

\section{Distribution of surge-type glaciers}

Results indicate that surge-type glaciers on Novaya Zemlya predominantly have a westerly aspect and are located in the west of the island (Figs 3 and 6). It is likely that this tendency is related to the predominant delivery of precipitation, which is $600 \mathrm{~mm} \mathrm{a}^{-1}$ greater in the west of Novaya Zemlya than in the east (Glazovsky, 2003). The low precipitation on the eastern side of Novaya Zemlya is likely to result in glaciers with lower surface mass balance, which are therefore unable to build up the mass flux required to generate a surge (Budd, 1975; Clarke and others, 1986). Indeed, we note that potential surge-type glaciers on eastern Novaya Zemlya are clustered towards the southeast of the northern island, where precipitation is higher than in the northeast.

It has also been argued (e.g. Dowdeswell and others, 1991; Copland and others, 2003) that in regions of relatively

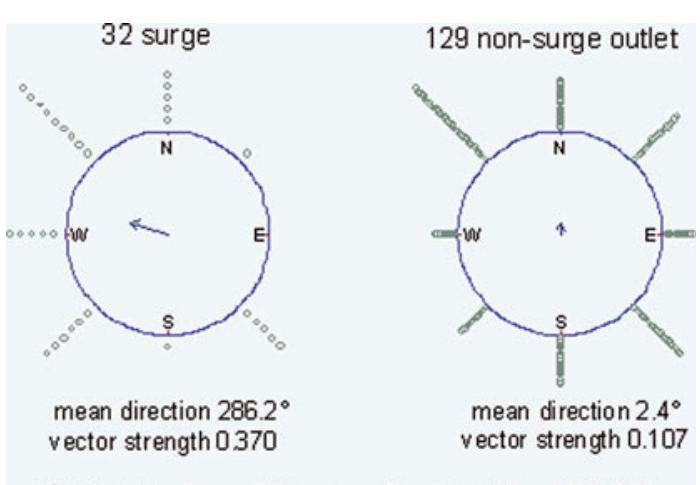

Outlet glaciers of Novaya Zemlya, N. of $74.25^{\circ}$

Fig. 6. Aspect of 32 surge-type and 129 other outlet glaciers. Each dot represents one glacier. 
low accumulation, such as the Canadian Arctic (0.06$0.1 \mathrm{~m}$ w.e.; Braun and others, 2004), the active surge phase is of longer duration (up to 50 years in the Canadian Arctic) and is less intense than in regions of higher accumulation (e.g. Iceland with 2.1 mw.e.; Björnsson, 1996). Thus, the lower accumulation rates on eastern Novaya Zemlya might also result in surge-type glaciers with much longer quiescent phases, which make them less likely to be identified.

The west-to-east climatic gradient on Novaya Zemlya is likely to be manifested in ice temperature and basal thermal regime, which has also been related to surge occurrence (Clarke and others, 1986). It has been postulated that there is a correlation between surging glaciers and a polythermal basal thermal regime (Hamilton and Dowdeswell, 1996; Jiskoot and others, 2000; Copland and others, 2003). Due to the marked decrease in temperature and precipitation in the east of Novaya Zemlya, one might expect the glaciers here to be colder, with predominantly cold-based ice limiting surge activity. Other concentrations of surge occurrence have been discovered in East Greenland (Jiskoot and others, 2003) and Svalbard (Jiskoot and others, 2000), where it has been suggested that glacier mass balance and surge occurrence might be related through topographic controls upon mass balance (e.g. topographic shading, snow distribution and variation in solar radiation), thereby indicating a possible indirect local climatic control.

Finally, subglacial geology is also known to be a possible factor affecting the distribution of surge-type glaciers (e.g. Post, 1969; Hamilton and Dowdeswell, 1996; Jiskoot and others 1998, 2000). Early work in North America suggested a possible link between glacier surging and fault-related valleys where bedrock is likely to be fractured and have a high permeability (Post, 1969). More recent work in Svalbard also found a relationship between glacier surging and more erodible and deformable sedimentary bedrock (Hamilton and Dowdeswell, 1996; Jiskoot and others, 2000). These studies (see also Harrison and Post, 2003) clearly highlight the potential importance of subglacial geology, particularly the availability of easily deformable sediments, in influencing the distribution of surge-type glaciers in a number of areas (i.e. Alaska, Yukon Territory and Svalbard).

Unfortunately, knowledge of subglacial geology beneath the glaciers in Novaya Zemlya is limited and it is not possible to ascertain the extent of 'hard' vs 'soft' bed conditions beneath the surge-type glaciers. The United States Geological Survey (USGS) Circumpolar Geologic Map of the Arctic (scale 1:6700 000; Persits and Ulmishek, 2003) provides information on geological age (but not lithology) and excludes subglacial areas. However, by analogy with the sediments and landforms observed in many Arctic fjords, from which ice has recently retreated (e.g. Ottesen and Dowdeswell, 2006; Ottesen and others, 2008), it is likely that most of the large tidewater glaciers entering fjords are underlain predominantly by deformable sedimentary material.

\section{Characteristics of surge-type glaciers}

Several studies have attempted to identify the characteristics of surge-type glaciers in order to better understand the possible mechanisms that lead to surge behaviour and, more generally, fast glacier flow (Clarke, 1991; Jiskoot and others, 1998). These studies indicate that glacier length is one of the most important factors determining surge 'probability', with surge-type glaciers characteristically much longer, on average, than non-surge-type glaciers (Clarke, 1991; Jiskoot and others, 1998). In Svalbard, for example, the median length of surge-type glaciers is $13.1 \mathrm{~km}$, compared to only $6.5 \mathrm{~km}$ for non-surge-type glaciers (Jiskoot and others, 1998). (In Jiskoot's study, the shortest surge-type glacier is $2 \mathrm{~km}$ long and the smallest is $1.8 \mathrm{~km}^{2}$.) The results from our study appear to support this pattern: the median glacier length for surge-type glaciers is $18.5 \mathrm{~km}$ compared with only $2.9 \mathrm{~km}$ for non-surge-type glaciers (Table 4). However, it should be remembered that surges of smaller glaciers may go unrecorded because any advance is likely to be much less significant than for larger glaciers (Clarke and others, 1986; Hamilton and Dowdeswell, 1996). Furthermore, many of the criteria used to identify surge-type glaciers are likely to be easier to detect on large glaciers, especially on satellite imagery. We also note that, in contrast to previous studies (e.g. Jiskoot and others, 1998), the statistical difference between surge- and non-surge-type glaciers was greatest for area, rather than length, although the two are strongly correlated with each other.

In addition to length and area relationships, surge-type glaciers are often associated with lower ice surface slopes compared with non-surge-type glaciers (e.g. Clarke, 1991; Björnsson and others, 2003; Jiskoot and others, 2003). Median slopes reported by Jiskoot and others (1998) were $3.1^{\circ}$ for surge-type and $5.1^{\circ}$ for other glaciers, but the steepest surge-type glacier was $14^{\circ}$, much steeper than in Novaya Zemlya. Our analysis of the surge-type glaciers on Novaya Zemlya supports the association of surging with gentler slopes (Fig. 4; Table 4), but it is important to note that surface slope is strongly linked to glacier length (Clarke, 1991). Our partial correlations suggest no association with slope or length beyond that accounted for by area.

It has also been reported that surge-type glaciers in some areas occupy higher overall elevations (Clarke and others, 1986) and cover greater elevation ranges (Jiskoot and others, 1998) than non-surge-type glaciers. However, our results show that surge-type glaciers have typically lower minimum and mid-range elevations than non-surge-type glaciers. This probably reflects the generally lower elevations on Novaya Zemyla and its large plateau ice cap, compared with other study areas. Furthermore, our dataset of 692 glaciers includes many smaller mountain and cirque glaciers located at high elevations in the south (mid-altitude up to $1050 \mathrm{~m}$ ), whereas the majority of surge-type glaciers terminate at sea level and emanate from the large plateau ice cap in the north.

There are 27 non-surge-type (type 4) glaciers with the six criteria shared by all surge-type glaciers (gently sloping outlet glaciers north of $74.25^{\circ} \mathrm{N}$, large on three size criteria). These merit further investigation for possible surging. The six criteria do not include aspect since 5 surge-type glaciers face southeast, or terminus since 10 surge-type glaciers are land-terminating. The proportion that is land-terminating is similar for surge-type glaciers and for these others. However, of the 57 glaciers with all six criteria (27 non-surge-type and 30 surge-type glaciers), 36 have aspects of southwest, west, northwest or north: of these, 23 (64\%) are surge-type. Beyond that, there may be currently unknown differences in subglacial topography that may inhibit surging in the other glaciers. Alternatively, the differences may be in the subglacial material. On the other hand, some of these glaciers may eventually surge. 
Finally, all surge-type glaciers on Novaya Zemlya are outlet glaciers within larger ice bodies (ice caps or icefields). This pattern is reflected across the Arctic where many surgetype glaciers are outlet glaciers, often terminating in the sea (Copland and others, 2003; Ottesen and others, 2008). Similarly, almost all surge-type glaciers in Iceland are outlets from larger ice bodies (Björnsson and others, 2003). On Novaya Zemlya, however, restriction to outlet glaciers may arise simply from glacier size. One hundred and sixteen outlet glaciers are $\geq 7 \mathrm{~km}$ long, but only three other glaciers are $\geq 7 \mathrm{~km}$ long; five are $7 \mathrm{~km}$ long and none are longer than $11 \mathrm{~km}$.

By their very nature, outlet glaciers and large/long glaciers often involve more complex flow than shorter valley or mountain glaciers which terminate on land. A relationship between glacier surging and complexity (complex flow and flow obstruction due to topographic controls) has been presented by Jiskoot and others (2000), and although this parameter was not measured in our study, we speculate that a similar relationship exists, because surging is more common in outlet glaciers with low surface slopes and large and complex catchment areas.

\section{Surge mechanism}

The inter-relationships between glacier surging, glacier length and area, and glacier surface slope have been linked to subglacial conditions and the mechanism of surging (e.g. Clarke, 1991; Jiskoot and others, 2000). The greater length and lower surface slopes are thought to be more conducive to a 'linked-cavity surge mechanism' (Kamb, 1987), whereby the organization of the subglacial drainage system impedes efficient evacuation of water, increasing basal water pressures and resulting in enhanced basal sliding during the surge phase. It has been pointed out, for example, that longer glaciers are more likely to encounter impeded subglacial drainage and that water is more likely to be stored under lower ice surface slopes (Clarke and others, 1986).

Other workers propose that glacier length is linked to surge behaviour because there is an increased probability of longer glaciers: (i) being thicker and able to store more water (e.g. Lingle and Fatland, 2003); (ii) overlying fine-grained tills (due to increased transport distances under the glacier) (Jiskoot and others, 2000); and (iii) experiencing a distancerelated decrease in longitudinal stress (Jiskoot and others, 2000). It should be remembered also that glacier length could be a proxy for other attributes related to surge initiation such as ice thickness or mass (Clarke and others, 1986). Moreover, where surge occurrence has been found with steeper ice surface gradients and/or where soft unconsolidated sediments underlie the glacier, the 'linkedcavity mechanism' is unlikely to occur, and others have proposed a mechanism related to switches in the basal thermal regime (e.g. Jiskoot and others, 2000). Indeed, as discussed earlier, the availability of soft fine-grained sediments has been linked to increased surge activity (Jiskoot and others, 1998, 2000; Harrison and Post, 2003; Ottesen and others, 2008). Whilst the greater length and low surface slopes of surge-type glaciers on Novaya Zemlya might favour a 'linked-cavity mechanism' over hard bedrock, the subglacial geology on Novaya Zemlya is largely unknown. It is equally plausible therefore, and arguably more likely in fjord settings (Ottesen and Dowdeswell, 2006; Ottesen and others, 2008), that mobilization of unconsolidated material at the glacier bed could be a significant factor in influencing surge behaviour. Improved knowledge of subglacial geology on Novaya Zemlya and its potential influence on glacier surging is an area that future work could address. More generally, there is also a clear need for an improved understanding of the interplay between subglacial till and the internal hydraulic system, which appears to be crucial to understanding the mechanisms of glacier surging (Harrison and Post, 2003)

\section{CONCLUSIONS}

The Novaya Zemlya archipelago supports $\sim 22984 \mathrm{~km}^{2}$ of ice, the majority of which forms a large ice cap on the north island. Over 690 glaciers have been documented in this region (Kotlyakov, 1978), but previous work suggested that these include only a small number of surge-type glaciers (four) (Dowdeswell and Williams, 1997; Sharov, 2005), despite the widespread occurrence of surging in other Arctic regions such as Svalbard and Greenland. We have used a variety of high-resolution satellite images from different dates to record the presence of glaciological (Copland and others, 2003) and geomorphological (Evans and Rea, 2003) criteria identifying surge-type glaciers, and to systematically document their occurrence.

A total of 32 potential surge-type glaciers are identified, which represent $4.6 \%$ of the total glacier population but $18 \%$ of the total glacier area (cf. $46-48 \%$ of area for Svalbard; Jiskoot and others, 1998). This increased detection, compared with previous studies, is likely to reflect the increased temporal (1976, 1989, 2001, 2006) and spatial (up to $4 \mathrm{~m}$ ) resolution of our satellite observations and implies that warm-based or polythermal conditions may be more widespread on Novaya Zemlya than previously recognized. In fact we expect warm-based conditions in deep outlet glaciers of the northwest coast, which are fed by considerable snowfalls.

Surge-type glaciers on Novaya Zemlya predominantly exhibit a westerly aspect and are located in the west of the island. They tend to be longer and larger, and exhibit lower surface slopes, than non-surge-type glaciers. They also tend to descend to lower elevations and are more likely to terminate in a marine or lacustrine environment than nonsurge-type glaciers. Statistically significant differences are found between surge-type and non-surge-type glaciers in terms of their area, length, overall surface slope, aspect, minimum elevation and mid-range elevation. They are also statistically different in terms of their terminus type, which favours a marine or lacustrine setting.

It is suggested that surge occurrence might be related to large and complex catchment areas found in the more maritime west, which receives increased delivery of precipitation from the Barents Sea. This implies that precipitation, in addition to glacier length or surface slope, is an important control on surge-type glaciers in this region.

Numerous studies have linked recent glacier retreat to climate change in the Arctic (e.g. Hagen and others, 2003; Howat and others, 2007), where warming is expected to be amplified (Serreze and Francis, 2006). The periodic cycle of advance and retreat of surge-type glaciers is not directly coupled to climate forcing, and the discovery of previously unidentified surge-type glaciers on Novaya Zemlya underlines the importance of investigating surge behaviour in these regions. 


\section{ACKNOWLEDGEMENTS}

This work was funded by a Reading University Research Endowment Fund studentship awarded to K. Grant. The authors are grateful to J. Dowdeswell and W. Harrison, whose comments improved the manuscript, and to Scientific Editor, J. Glen. We also thank M. Shahgedanova, S. Gurney and K. White from the Department of Geography, Reading University.

\section{REFERENCES}

Arendt, A.A., K.A. Echelmeyer, W.D. Harrison, C.S. Lingle and V.B. Valentine. 2002. Rapid wastage of Alaska glaciers and their contribution to rising sea level. Science, 297(5580), 382-386.

Björnsson, H. 1996. Iceland. In Jania, J. and J.O. Hagen, eds. Mass balance of Arctic glaciers. Sosnowiec/Oslo, International Arctic Science Committee, 25-29. (IASC Report 5.)

Björnsson, H., F. Pálsson, O. Sigurðsson and G.E. Flowers. 2003. Surges of glaciers in Iceland. Ann. Glaciol., 36, 82-90.

Braun, C., D.R. Hardy and R.S. Bradley. 2004. Mass balance and area changes of four high Arctic plateau ice caps, 1959-2002. Geogr. Ann., 86A(1), 43-52.

Bruce, R.H., G.A. Cabrera, J.C. Leiva and L.E. Lenzano. 1987. Correspondence. The 1985 surge and ice dam of Glaciar Grande del Nevado del Plomo, Argentina. J. Glaciol., 33(113), 131-132.

Budd, W.F. 1975. A first simple model for periodically self-surging glaciers. J. Glaciol., 14(70), 3-21.

Clarke, G.K.C. 1987. Fast glacier flow: ice streams, surging and tidewater glaciers. J. Geophys. Res., 92(B9), 8835-8841.

Clarke, G.K.C. 1991. Length, width and slope influences on glacier surging. J. Glaciol., 37(126), 236-246.

Clarke, G.K.C., J.P. Schmok, C.S.L. Ommanney and S.G. Collins. 1986. Characteristics of surge-type glaciers. J. Geophys. Res., 91(B7), 7165-7180.

Copland, L., M.J. Sharp and J.A. Dowdeswell. 2003. The distribution and flow characteristics of surge-type glaciers in the Canadian High Arctic. Ann. Glaciol., 36, 73-81.

Dowdeswell, E.K., J.A. Dowdeswell and F.G.L. Cawkwell. 2007. On the glaciers of Bylot Island, Nunavut, Arctic Canada. Arct. Antarct. Alp. Res., 39(3), 402-411.

Dowdeswell, J.A. and M. Williams. 1997. Surge-type glaciers in the Russian High Arctic identified from digital satellite imagery. J. Glaciol., 43(145), 489-494.

Dowdeswell, J.A., G.S. Hamilton and J.O. Hagen. 1991. The duration of the active phase on surge-type glaciers: contrasts between Svalbard and other regions. J. Glaciol., 37(127), $388-400$

Dyurgerov, M. and G.J. McCabe. 2006. Associations between accelerated glacier mass wastage and increased summer temperature in coastal regions. Arct. Antarct. Alp. Res., 38(2), 190-197.

Eisen, O., W.D. Harrison and C.F. Raymond. 2001. The surges of Variegated Glacier, Alaska, U.S.A., and their connection to climate and mass balance. J. Glaciol., 47(158), 351-358.

Evans, D.J.A. and B.R. Rea. 2003. Surging glacier landsystem. In Evans, D.J.A., ed. Glacial landsystems. London, Edward Arnold.

Evans, D.J.A., D.R. Twigg, B.R. Rea and M. Shand. 2007. Surficial geology and geomorphology of the Bruarjökull surging glacier landsystem. J. Maps, 2007, 349-367.

Glazovskiy, A.F. 1996. Russian Arctic. In Jania, J. and J.O. Hagen, eds. Mass balance of Arctic glaciers. Sosnowiec/Oslo, International Arctic Science Committee, 25-29. (IASC Report 5.)

Glazovsky, A.F. 2003. Glacier changes in the Russian Arctic. In Casey, A., ed. Workshop on Assessing Global Glacier Recession. Boulder, CO, World Data Center for Glaciology, 78-82. (Glaciological Data Report GD-32.)

Glazovskiy, A.F. and Yu.Ya. Macheret. 2006. Novaya Zemlya. In Kotlyakov, V.M., ed. Oledenenie Severnoj i Central'noj Evrazii v
Sovremennuju epochu [Glaciation in north and central Eurasia at present time]. Moscow, Nauka. [In Russian.]

Hagen, J.O., K. Melvold, F. Pinglot and J.A. Dowdeswell. 2003. On the net mass balance of the glaciers and ice caps in Svalbard, Norwegian Arctic. Arct. Antarct. Alp. Res., 35(2), 264-270.

Hamilton, G.S. and J.A. Dowdeswell. 1996. Controls on glacier surging in Svalbard. J. Glaciol., 42(140), 157-168.

Harrison, W.D. and A.S. Post. 2003. How much do we really know about glacier surging? Ann. Glaciol., 36, 1-6.

Howat, I.M., I.R. Joughin and T.A. Scambos. 2007. Rapid changes in ice discharge from Greenland outlet glaciers. Science, 315(5818), 1559-1561.

Jiskoot, H., P. Boyle and T. Murray. 1998. The incidence of glacier surging in Svalbard: evidence from multivariate statistics. Comput. Geosci., 24(4), 387-399.

Jiskoot, H., T. Murray and P. Boyle. 2000. Controls on the distribution of surge-type glaciers in Svalbard. J. Glaciol., 46(154), 412-422.

Jiskoot, H., T. Murray and A. Luckman. 2003. Surge potential and drainage-basin characteristics in East Greenland. Ann. Glaciol., 36, 142-148.

Kamb, B. 1987. Glacier surge mechanism based on linked cavity configuration of the basal water conduit system. J. Geophys. Res., 92(B9), 9083-9100.

Kjær, K.H., N.J. Korsgaard and A. Schomacker. 2008. Impact of multiple glacier surges: a geomorphological map from Bruar jökull, East Iceland. J. Maps, 2008, 5-20.

Koryakin, V.S. 1974. O podvizhkakh lednikov v Arktike [On glacier surges in the Arctic]. Mater. Glyatsiol. Issled. 24, 140-145. [In Russian with English summary.]

Kotlyakov, V.M., ed. 1978. Catalogue of glaciers USSR: Volume 3, Northern Area, Part 2, Novaya Zemlya [Katalog lednikov SSSR, Tom 3, Severnyj Kraj, Chast' 2 Novaja Zemlja]. Leningrad, Hydrometeoizdat. [In Russian.]

Lemke, P. and 10 others. 2007. Observations: changes in snow, ice and frozen ground. In Solomon, S. and 7 others, eds. Climate change 2007: the physical science basis. Contribution of Working Group I to the Fourth Assessment Report of the Intergovernmental Panel on Climate Change. Cambridge, etc., Cambridge University Press, 337-383.

Lingle, C.S. and D.R. Fatland. 2003. Does englacial water storage drive temperate glacier surges? Ann. Glaciol., 36, 14-20.

Meier, M.F. and A. Post. 1969. What are glacier surges? Can. J. Earth Sci., 6(4), 807-817.

Ottesen, D. and J.A. Dowdeswell. 2006. Assemblages of submarine landforms produced by tidewater glaciers in Svalbard. J. Geophys. Res., 111(F1), F01016. (10.1029/2005JF000330.)

Ottesen, D. and 9 others. 2008. Submarine landforms characteristic of glacier surges in two Spitsbergen fjords. Quat. Sci. Rev., 27(15-16), 1583-1599.

Pachauri, R.K. and A. Reisinger, eds. 2007. Climate change 2007: Synthesis Report. Contribution of Working Groups I, II and III to the Fourth Assessment Report of the Intergovernmental Panel on Climate Change. Geneva, Intergovernmental Panel on Climate Change.

Persits, F.M. and G.F. Ulmishek. 2003. Maps showing geology, oil and gas fields, and geologic provinces of the Arctic. USGS Open File Rep. 97-470-J.

Post, A. 1969. Distribution of surging glaciers in western North America. J. Glaciol., 8(53), 229-240.

Raup, B., A. Racoviteanu, S.J.S. Khalsa, C. Helm, R. Armstrong and Y. Arnaud. 2007. The GLIMS geospatial glacier database: a new tool for studying glacier change. Global Planet. Change, 56(1-2), 101-110.

Serreze, M.C. and J.A. Francis. 2006. The Arctic amplification debate. Climatic Change, 76(3-4), 1573-1480.

Sharov, A.I. 2005. Studying changes of ice coasts in the European Arctic. Geo-Mar. Lett., 25(2-3), 153-166.

UNESCO/International Association of Scientific Hydrology (IASH). 1970. Perennial ice and snow masses: a guide for compilation 
and assemblage of data for a world inventory. Paris, UNESCO/ International Association of Scientific Hydrology. (Technical Papers in Hydrology 1.)

Zeeberg, J.J. 1997. New data concerning the glacial history of the Barents Sea. In Gawronski, J.H. and P.V. Boyarsky, eds. Northbound with Barents. Amsterdam, Jan Mets, 62-71.
Zeeberg, J.J. and S.L. Forman. 2001. Changes in glacier extent on north Novaya Zemlya in the twentieth century. Holocene, 11(2), 161-175.

Zeeberg, J.J., S.L. Forman and L. Polyak. 2003. Glacier extent in a Novaya Zemlya fjord during the 'Little Ice Age' inferred from glaciomarine sediment records. Polar Res., 22(2), 385-394.

MS received 8 April 2009 and accepted in revised form 7 October 2009 